\title{
Nelegalaus darbo kontrolės efektyvumo problema Lietuvoje
}

\author{
Aleksandras Patapas, Nerijus Gudonis \\ Mykolo Romerio universitetas \\ Valakupiug. 5, LT-10101 Vilnius \\ doi:10.13165/VPA-14-13-4-09
}

\begin{abstract}
Anotacija. Nelegalu darba kontroliuojančiu instituciju veikla Lietuvoje pastaraisiais metais yra žymiai suaktyvejjusi, nustatoma dangiau pažeidèjų, tačian tai nepanaikina nelegalaus darbo atsiradimo priežasčiu. Dèl šios neteisètos veiklos kenčia ne tik valstybès biudžetas, nes negauna nemenkos dalies pajamu, bet ir patys nelegaliai dirbantys asmenys, atimantys iš savęs teisę gauti valstybès socialines garantijas. Atsižvelgdami i tai autoriai analizuoja nelegalaus darbo kontrolès efektyvumo aspektus per nelegalaus darbo reiškinius kontroliuojančiu instituciju prizmę, taip pat valstybès vykdoma socialinę ekonomine politika. Remiantis atlikta analize daroma išvada, kad nelegalaus darbo kontrolès efektyvumo problema gali büti išspręsta transformuojant valstybès vykdoma socialine ekonomine politika, nelegalaus darbo kontrolès teisine bazę, keliant pareigūnu kvalifikacija, tobulinat kontroliuojančiu instituciju materialinę, informacinę bei techninę bazę, tobulinant kontroliuojančiu institucijų koordinavimo priemones.
\end{abstract}

Reikšminiai žodžiai: nelegalus darbas, kontrolès efektyvumas, socialine ekonominè politika.

Keywords: undeclared work, control efficiency, social-economic policy.

\section{İvadas}

Bendrovė „Sprinter tyrimai“ dar $2010 \mathrm{~m}$. vasarą „Swedbanko“ Asmeninių finansų instituto užsakymu atliko tyrimą, kuris atskleide, kad net 54 proc. oficialiai nedirbančiu asmenų gauna pajamų, susijusių su įvairia darbo veikla. Išreiškus absoliučiais skaičiais paaiškèjo, ,kad daugiau nei 160 tūkst. oficialiai nedirbančių šalies gyventojų pajamų gauna iš nuolatinio arba laikino nelegalaus darbo“ [14]. Be 
to, kiti tyrimai parodo dar didesni nelegalaus darbo mastą Lietuvoje. Jau $2010 \mathrm{~m}$. rugsèjo ménesị Lietuvos laisvosios rinkos instituto atlikto tyrimo duomenys rodo, kad „,̌̌šèlinè ekonomika Lietuvoje sudaro 27 proc. bendro vidaus produkto (toliau BVP), o tai yra apie 30 mlrd. Lt. Net 23 proc. visos šešelinès ekonomikos, arba šiek tiek daugiau nei $7 \mathrm{mlrd}$. Lt, sudaro nelegalus darbas ir neoficialus darbo užmokestis, mokamas „vokeliuose“ [14]. 2012-2013 m. atliktame Lietuvos ekonomikos tyrime teigiama, kad šešèlinė ekonomika palaipsniui mažèja ir 2013 m. gali nukristi iki 26 proc. BVP [26].

Nelegalų darbą kontroliuojančių institucijų statistinè informacija atskleidžia, kad nelegalaus darbo mastai pastaruoju metu dideja. $2012 \mathrm{~m}$. nelegalaus darbo atvejų užfiksuota tris kartus daugiau nei $2011 \mathrm{~m}$. per tą pati laikotarpị. Lietuvos Respublikos socialinès apsaugos ir darbo ministerijos duomenimis, $2012 \mathrm{~m}$. Lietuvos Respublikos valstybinė darbo inspekcija prie Socialinès apsaugos ir darbo ministerijos (toliau VDI) teismams perdavė 195 bylas, jose paskirta daugiau nei 415 tūkst. Lt baudų, o tai yra pusantro karto daugiau nei $2011 \mathrm{~m}$. [18]. $2013 \mathrm{~m}$. VDI duomenimis, teismams perduotos 258 bylos ir darbdaviams skirta baudų už 796 tūkst. Lt. Atsižvelgdami ị tai autoriai siekia įvertinti esamą padètị Lietuvos nelegalaus darbo kontrolès efektyvumo srityje ir numatyti šių problemų sprendimo kryptis. Straipsnio tikslas - atlikti nelegalaus darbo atsiradimo priežasčių teorinę analizę, įvertinti nelegalaus darbo kontrolę Lietuvoje ir Europos Sąjungoje, atlikti Lietuvos nelegalaus darbo kontrolès efektyvumo analizę.

Straipsnyje taikomi tyrimo metodai: Lietuvos Respublikos įstatymų ir kitų teisès aktų analizė; Europos Sąjungos dokumentų analizė; mokslinès literatūros sisteminè analizé; statistinių duomenų analizė; ekspertinis tyrimas (apklausa).

\section{Nelegalaus darbo reiškinio formavimosi teoriniai aspektai}

Nelegalus darbas dažnai ịvardijamas skirtingais pavadinimais. Tokios sąvokos kaip ,juodasis darbas“, „,nedeklaruojamas darbas“, „,neoficialus užimtumas“, „,neoficialus darbas“, ,paslèptas nedarbas“ ir daugelis kitų pavadinimų yra vartojami apibūdinti šị paradoksalų reiškinị.

J. Krumplytès nuomone, nelegalaus darbo reiškinys yra šešèlinės ekonomikos sudètinè dalis. Ji teigia, kad „Šešèlinè ekonomika daro neigiamą įtaką šalies ekonominei ir socialinei raidai, pasireikšdama nelegalaus darbo ir neapskaitomų pajamų augimu, socialinès diferenciacijos plètra ir nepasitikejjimo valstybe bei korupcijos lygio kilimu“" [7, p. 238]. Reikia sutikti, kad nelegalaus darbo reiškinị reikia suprasti kaip sudètinę šešèlinès ekonomikos dalị, tačiau ji dažniausiai susijusi su darbo santykiais, kai esant darbo sutarties požymiams neįforminama rašytine darbo sutartis arba nepranešama mokesčių administratoriui apie pradėtą veiklą. Taip pat nelegalus darbas slepiamas po ne viso darbo laiko apskaitos skraiste. Kartu su nelegaliu darbu žengia ir neapskaitytas apmokèjimas už darbą, paprasčiau vadinamas ,vokeliais“. Analizuojant Europos Komisijos komunikatą apie nelegalų darbą aiškejja, kad nele- 
galiais darbuotojais dažniausiai tampa asmenys, turintys du ir daugiau darbų; ,,ekonomiškai neaktyvūs asmenys“ (šis terminas apima studentus, namų šeimininkes, anksti išejjusius į pensiją asmenis ir kt.); bedarbiai; trečiųjų šalių piliečiai [1]. Taip pat pranešime teigiama, kad pagrindinè šešèlinès ekonomikos ir nelegalaus darbo atsiradimo ir gyvavimo priežastis yra pati ekonomika [1]. Europos ekonomikos ir socialinių reikalų komitetas mano, kad sąlygas tapti nelegaliu darbuotoju sudaro i̇monès, kurios sistemingai organizuoja nelegalų darbą, kurị paprastai derina su legalia veikla ir tokių įmonių darbuotojai atlygị už darbą dažniausiai gauna neoficialiai [3].

Europos Sajungos valstybėse nelegalaus darbo apimtys ir mastai skiriasi. Tai priklauso nuo ịvairių kiekvienos valstybės narės ekonomikos aspektų. Pirmiausia nuo mokesčių ir socialinio draudimo įmokų lygio, taip pat nuo bendrųjų išlaidų ir administracinių procedūrų naštos. Reikia nepamiršti ir to, kaip kiekvienos valstybès gyventojai kultūriškai priima šešèlinès ekonomikos ir kartu nelegalaus darbo reiškinius [25]. Europos Komisijos turimi duomenys apie bendrą nelegalaus darbo valstybėse narèse mastą rodo, kad ne tik nelegalaus darbo apimtys, bet ir ypatumai Europos Sąjungos valstybése labai skiriasi - kai kuriose pietinėse ir rytinése Europos valstybėse jis sudaro 20 proc. BVP ar viršija ši skaičių [6]. Europos Komisijos pateiktoje nelegalaus darbo išsiplètusioje Europos Sąjungoje analizejje teigiama, kad Lietuvoje nelegalus darbas yra susijęs su ,,pasitikèjimo valstybès institucijomis stoka, silpna viešojo administravimo sistema, sunkia mokesčių našta, ydinga mokesčių administravimo sistema, sudėtingomis apskaitos taisyklèmis, netobula ir nenuspejjama teisine sistema, korupcija“"[23].

Statistikos žurnalo straipsnyje „Neoficialaus užimtumo apimties įvertinimas“ taip pat pabrèžiama, kad nelegalus darbas nėra tik mūsų valstybės problema, ji egzistuoja ir daugelyje Vakarų Europos valstybių, tačiau šio reiškinio apimtys yra žymiai mažesnès [20, p. 6].

A. Pocius ir kt. mano, kad „Lietuvoje, kaip ir kitose postkomunistinėse šalyse, susiformavo sudėtinga specifinė darbo rinkos struktūra. Be pagrindinių darbo rinkos segmentų (oficialusis užimtumas ir registruotas nedarbas), kurie ypač ryškūs Vakarų Europos šalyse, mūsų šalies ūkyje susiformavo dar du (paslėptas nedarbas ir neoficialus užimtumas)“" [20, p. 6].

B. Martinkus ir kt. mano, kad viena iš priežasčių, kodèl atsiranda nelegalaus darbo reiškinys, yra oficialaus darbo neradimas. Žmonėms reikia išmaitinti savo šeimas, mokèti už ịvairias paslaugas. Todèl šie asmenys yra priversti ieškoti bet kokio darbo. O toks darbas dažnai būna ne visos darbo dienos darbas ar žemesnès kvalifikacijos, nei turi asmuo, darbas, todell labai dažnai toks darbas būna nelegalus ir ịvardijamas kaip ,paslèptas nedarbas“ $[15$, p. 86]. Dar viena priežastis yra ta, kad didelè dalis asmenų tik deklaruoja, kad ieško darbo, tačiau tai tik paslèptas melas, siekiant gauti bedarbio pašalpą ar socialinio aprūpinimo pašalpą. Šios išmokos gaunamos tik tuo atveju, jei asmuo yra užsiregistravęs Lietuvos darbo biržoje ir nustatytu laiku atvyksta ị Lietuvos darbo biržą, o kitu laiku jis dažniausiai dirba 
nelegaliai. Pasak B. Martinkaus ir kt., „toks nedarbas vadinamas šešėliniu nedarbu“. Teigiama, kad „paslëptasis nedarbas ir neoficialus užimtumas apima 15-20 proc. ekonomiškai aktyvių Lietuvos gyventojų“ $[15$, p. 87].

Nedeklaruojama ekonominè veikla, iš vienos pusès, tai tik neteisèta veikla, tačiau pažvelgus iš kitos pusès, ši neteisèta veikla sukuria didžiuli kelių pakopu pajamų stygių, kurios turi ịplaukti ị valstybès biudžetą. Išryškèja ir ekonominè nelegalaus darbo pasekmé - mokesčių institucijos surenka mažiau pajamų mokesčio ir pridètinès vertès mokesčio, ir socialinè nelegalaus darbo pasekmè - socialinès apsaugos institucijos negauna ịmokų iš nedeklaruotos veiklos, o tai žlugdo visos socialinès apsaugos sistemos darbą, ji negali garantuoti socialinio saugumo šalies gyventojams [15, p. 87]. Todèl galima teigti, kad nelegalaus darbo reiškinys formuojasi dèl neefektyvios valstybės ekonominès ir socialinės politikos formavimo ir igyvendinimo.

Analizuojant valstybės vykdomą ekonominę politiką, neišvengiamai susiduriama su jos sudedamąja dalimi - fiskaline politika, kuria siekiama užtikrinti valstybės pajamas remiantis mokesčiu sistema. Visi legaliai dirbantys fiziniai ir juridiniai asmenys, veikiantys pagal Lietuvos Respublikos darbo kodeksą ir vykdantys mokestinius ịsipareigojimus valstybei, susiduria su tam tikra mokesčių našta, kurios dydis gali sudaryti prielaidas nelegalaus darbo reiškiniui atsirasti.

Mokesčių našta skiriama ị tris tipus: tiesioginę, netiesioginę ir paslėptąją. Tiesioginè mokesčių našta - tai tokia pinigų suma, kurią mokesčių mokètojas sumoka ị valstybès biudžetą. Šie mokesčiai gali būti išmatuojami tiek absoliučia suma, tiek santykinai, pavyzdžiui, lyginant su BVP. Antroji -netiesioginė mokesčių našta ìvardijama kaip mokesčių administravimo išlaidos. Trečioji - paslëptoji mokesčių našta. Jos negalima išmatuoti ir dažnai jos įtaką sunku pastebèti, bet ji paprastai egzistuoja prie kiekvieno mokesčio [17].

Belgijos „Naujoji kryptis - Europos reformų fondo“ ir Prancūzijos „Molinari“ ekonomikos instituto Europos Sajungos mastu atlikti tyrimai atskleidè, kad mūsų valstybẻ patenka ị sunkiausią mokesčių naštą turinčių šalių dešimtuką, pralenkdama net Daniją ir Suomiją, taip pat Estiją ir Lenkiją [11]. „PricewaterhouseCoopers“ ir Pasaulio banko parengta mokesčių mokejjimo tyrimo ataskaita „Paying Taxes 2012“ taip pat rodo, kad mokesčiai Lietuvoje nèra maži. Vertinant mokesčių naštą ir mokesčių mokẻjimo paprastumą, Lietuva 2012 m. nukrito iš 44-os ị 57-ą vietą (iš nagrinètų 183 šalių). Mūsų valstybẻ santykinai geriau ịvertinta mokesčių mokèjimo dažnumo kategorijose, kur ji užima 40-ą vietą, tačiau žemyn mus nustumia tik mokesčių dydis, pagal kurị mes esame 115-oje vietoje pasaulyje. „Šioje kategorijoje mus lenkia net tokios tradiciškai „didelių mokesčių šalimis“ vadinamos šalys kaip Danija (33-a vieta) ir Suomija (92-a vieta). Ekspertų skaičiavimu, Lietuvoje bendras vidutinei įmonei tenkantis apmokestinimas sudaro 43,9 proc. pelno, tuo tarpu Suomijoje apmokestinimas sudaro 38,7 proc., o Danijoje - tik 27,5 proc.“ [10] Šią dvilypę situaciją galima paaiškinti tik tuo, kad egzistuoja skirtingi požiūriai ị mokesčiu naštą ir nėra vienos mokesčių skaičiavimo metodikos. Privataus sektoriaus 
atstovai akcentuoja, kad mokesčių yra per daug ir jų tarifai yra per dideli. Politikų skelbiama mokesčių našta remiasi surenkamų mokesčių ir BVP santykiu ir gali atrodyti nedidelè ir efektyvi. Kiekvienas požiūris iš dalies teisingas, tačiau nominali ir faktinè mokesčių našta skiriasi. Todèl ir pati sistema tampa neteisinga ir valstybès socialinė ekonominè sistema vystoma neteisinga kryptimi [8]. Lyginant šiuos duomenis galima teigti, kad Lietuvoje mokesčiai yra gana dideli, o mokesčių surinkimas yra vienas mažiausių Europos Sąungoje. Reikia pabrèžti, kad maži mokesčiai ir mažas mokesčių surinkimas nėra tie patys dalykai. Mažas mokesčių surinkimas gali būti didelių mokesčių išdava, tuo pat metu tai gali būti vengimo mokèti didelius mokesčius pasekmè.

Analizuojant valstybès vykdomą socialinę politiką reikia apibrèžti, kad „Lietuvoje socialinè apsauga apima tris sudetines dalis - socialinị draudimą, socialinę paramą ir specialiąsias (papildomas) socialines išmokas" [5]. Lietuvoje, kaip daugelyje kitų pereinamojo laikotarpio valstybių, dažniausiai socialines problemas bandoma išspręsti naudojantis valstybès, savivaldybių biudžeto ir įvairių valstybinio draudimo fondų léšomis [22, p. 515], o mūsų valstybès surenkamų biudžeto pajamų santykis lyginant su BVP ir remiantis „Eurostat“ $2011 \mathrm{~m}$. duomenimis yra pats mažiausias visoje Europos Sajungoje ir tesiekia apie 32 proc. [21]. Todèl nenuostabu, kad ir išlaidos socialinei apsaugai Lietuvoje yra vienos mažiausių Europos Sąjungoje. 2010 m. „Eurostat“ duomenimis, šis rodiklis tesiekè 19,1 proc. BVP [12]. Beje, nacionalinio biudžeto analizè negali visko atskleisti, nes valstybès biudžetas finansuoja ne visas socialines išlaidas. Kitos dalys finansuojamos iš kitų valstybinio draudimo fondų [22]. Tačiau galima manyti, kad valdžios dėmesys socialinei politikai yra nepakankamas, todèl jis negali užtikrinti žmonių socialinio saugumo jausmo. Todèl Lietuvoje turime tokią socialinès apsaugos sistemą: nuolat ,alkaną“ bei gana komplikuotą, absoliučiomis sumomis menką socialinę paramą pinigais ir paslaugomis [24]. Tam, be abejonės, didžiulę ịtaką turi valstybés ekonominė politika, kuri pasižymi sunkia mokesčių našta.

Remiantis atlikta literatūros ir statistikos duomenų analize galima daryti išvadą, kad valstybés vykdoma ekonominè ir socialinė politika sudaro sąlygas atsirasti nelegalaus darbo reiškiniui Lietuvoje. Nepaisant politikų deklaruojamos efektyvios mokesčių naštos nustatyta, kad valstybės vykdoma ekonominė ir socialinė politika, paremta didele mokesčių našta, neatitinka patvirtintų socialinès ekonominès politikos iškeltų tikslų kurti stabilią makroekonominę aplinką, kuri paremta konkurencingu, sparčiu ekonomikos augimu, žemu nedarbo lygiu ir stabiliomis kainomis.

\section{Nelegalaus darbo kontrolès ịvertinimas Lietuvoje ir Europos Sąjungoje}

Siekiant surasti darnius politinius metodus ir priemones, kurie užkirstų kelią nelegaliam darbui ir padidintų nelegalaus darbo efektyvumo kontrolę, iniciatyvos ėmèsi Europos gyvenimo ir darbo sąlygų gerinimo fondas „Eurofound“. 2008 m. paskelbtoje priemonių, kuriomis siekiama kovoti su nelegaliu darbu Europos 
Sąjungoje, ataskaitoje buvo padèti pagrindai bendrai Europos kovos su nedeklaruojamu darbu platformai sukurti, kurioje būtų skelbiama šalių informacija apie vykdomą politiką, priemones, nelegalaus darbo mastus, jo pasiskirstymą ir kita naudinga informacija, reikalinga kovai su nelegaliu darbu [16]. „Šioje duomenų bazèje atkreiptas dėmesys ị taikytus kai kurių rūšių metodus, įskaitant atgrasomąsias priemones, prevencinius metodus, politiką, kuria siekiama įteisinti nedeklaruotą darbą ir kampanijas, kuriomis siekiama paskatinti kuo daugiau įmonių ir darbuotojų laikytis mokesčių reguliavimo ịstatymų.“ [4] Ši duomenų bazè, be abejo, padès kiekvienai šaliai atsirinkti geriausias priemones ir pritaikyti savo šalių praktikoje.

Europos Komisijos nuomone, nelegalus darbas yra sudètingas reiškinys, kuris trukdo igyvendinti socialinius ir ekonominius tikslus, taip pat konstatuoja, kad nelegalaus darbo reiškinys reikalauja vienodo ir subalansuoto požiūrio i t prevencijos ir teisèsaugos sritis. Taip pat būtina, kad šalių vyriausybės vykdytų atsakingą ekonominę ir socialinę politiką, kuri sumažintu paskatas darbdaviams ir darbuotojams užsiimti nelegaliu darbu. Nelegalaus darbo kontrolè reikalauja nemažai išlaidų. Todèl reikia sudaryti platesni politikos vaizdą, mažinant kontroliuojančių institucijų darbo naštą, igyvendinant atsakingesnę ekonominę ir socialinę politiką. Noras surasti efektyviausią būdą kovoti su nelegalaus darbo reiškiniu reikalauja bendros strategijos, kurioje būtų sujungtas ne vienas elementas, t. y. gerai koordinuoti metodai tarp administruojančių institucijų nacionaliniu ir tarptautiniu lygiu, informavimo, prevencijos ir sankcijų, taip pat socialinių partnerių ir teisminių institucijų dalyvavimo derinio [9]. Kovai su nelegaliu darbu kai kurios valstybès yra pasirašiusios bendradarbiavimo sutartis. Tačiau kiekviena šalis paprastai vykdo kontrolę nacionaliniu mastu, remdamasi savo kontrolès institucijų sistema. Nors daugelis valstybiu kovoja su nelegaliu darbu naudodamos savitas sistemas, tačiau dažniausiai kontrolès institucijų junginius sudaro kelios bendradarbiaujančios institucijos, ir yra viena pagrindinè institucija, tiesiogiai kovojanti su nelegaliu darbu [2]. Daugelyje valstybių dèmesys sutelkiamas ị skirtingas sritis, tačiau dažniausiai ị dvi: į mokesčių - Šiaurès, Pietų ir Vakarų Europoje, ir ị darbo teisę Rytų Europos šalyse.

Lietuvos, kaip ir daugelio postkomunistinių valstybių, nelegalaus darbo kontrolès veikla ryškiausia darbo teisės srityje. Kaip ir daugelyje Europos Sąjungos valstybių, mūsų šalyje nelegalaus darbo kontrolè vyksta bendradarbiaujant kelioms institucijoms, tačiau pagrindinè institucija, turinti kontroliuoti nelegalaus darbo reiškinius, yra VDI. VDI buvo pavesta koordinuoti „Sodros“, Valstybinės mokesčių inspekcijos, Finansinių nusikaltimų tyrimo tarnybos, Policijos departamento ir VDI teritorinių skyrių vykdomus nelegalaus darbo reiškinių kontrolès veiksmus. Kasmet Nelegalaus darbo reiškinių atsiradimo sąlygų nagrinejjimo ir jo kontrolès centrinė koordinavimo grupė priima nelegalaus darbo kontrolès ir prevencijos stiprinimo veiksmų planą, kuriuo siekiama mažinti nelegalaus darbo reiškinio paplitimo mastus [19]. Remiantis Nelegalaus darbo koordinavimo grupés reglamentu, parengtu vykdant Lietuvos Respublikos Vyriausybès nutarimą [13] ir patvirtintą Vyriausiojo 
valstybinio darbo inspektoriaus $2002 \mathrm{~m}$. vasario $21 \mathrm{~d}$. įsakymu $\mathrm{Nr}$. 40, Nelegalaus darbo koordinavimo grupè nagrinejja ịvairias nelegalaus darbo reiškinių formas, jų atsiradimo sąlygas ir priežastis, priima sprendimus dèl pagrindinių prevencijos krypčių ir metodų, aprobuoja bendrąsias nelegalaus darbo reiškinių apskaitos formas, analizuoja duomenis, susijusius su teisinès atsakomybės taikymu nelegalaus darbo reiškinių bylose, svarsto ir aprobuoja pasiūlymus dèl su nelegalaus darbo reiškiniais susijusios teisinès bazès tobulinimo, analizuoja užsienio valstybių nelegalaus darbo reiškinių kontrolès praktiką ir rengia pasiūlymus dèl jos taikymo Lietuvoje ir kt.

\section{Lietuvos nelegalaus darbo kontrolès efektyvumo analizė}

Siekiant ịvertinti esamą situaciją Lietuvos nelegalaus darbo kontrolès efektyvumo srityje ir numatyti šių problemų sprendimo kryptis, buvo atliktas ekspertinis tyrimas (apklausa). Naudojant iš dalies struktūrizuotą apklausos anketą norèta sužinoti ekspertų nuomonę apie VDI nelegalaus darbo kontrolès efektyvumą, taip pat ịvertinti esamą padètį Lietuvos nelegalaus darbo kontrolès efektyvumo srityje. Kadangi VDI yra pavesta koordinuoti „Sodros“, Valstybinès mokesčių inspekcijos, Finansinių nusikaltimų tyrimų tarnybos, policijos ir VDI teritorinių skyrių vykdomus nelegalaus darbo reiškinių kontrolès veiksmus, sudarant vertinimo grupę, ekspertai buvo pasirinkti iš VDI specialistų, kurie susiję su nelegalaus darbo kontrole. Atliekant kokybinị, empirinio pobūdžio tyrimą, analizuojamos specialistų ekspertų, dirbančių nelegalaus darbo kontrolès srityje, nuomonès ir jų pasiskirstymas. Naudojant tyrimo metu gautus duomenis siekta įvertinti VDI nelegalaus darbo kontrolès efektyvumo dabartinę būklę, esamą padètị Lietuvos nelegalaus darbo kontrolès efektyvumo srityje, numatyti ir pateikti nelegalaus darbo kontrolès efektyvumo problemos sprendimo kryptis. Apklausos metu gauti duomenys apdoroti atvejo tyrimo duomenų analizès būdu, sisteminant atsakymus pagal jų panašumus ir skirtumus.

Atlikus tyrimo duomenų analizę nustatyta, kad pagrindinės nelegalaus daro reiškinio atsiradimo priežastys Lietuvoje yra valstybès socialinė ekonominė aplinka ir žmonių požiūris ị nelegalaus darbo reiškinius. Kaip viena iš pagrindinių nelegalaus darbo atsiradimo priežasčių Lietuvoje buvo nurodyta prasta ekonomine padètis. Asmenys imasi nelegalaus darbo arba neregistruotos (neteisètos) veiklos dẻl mažo darbo užmokesčio, gaunamų pajamų. Kita ne mažiau svarbi nelegalaus darbo atsiradimo priežastis - didelė mokesčiu našta, kuri turi įtakos darbdavių ir darbuotojų norui nuslëpti mokesčius valstybei bei nelegalius darbo santykius. Dar vienas ekspertų pateiktas argumentas, kodèl atsiranda nelegalaus darbo reiškinys, - nesubalansuota socialinès paramos sistema. Valstybès parama - nedarbo išmokos, socialinės pašalpos ir kitos išmokos turi ịtakos žmonių sprendimams dirbti ar nedirbti, taip pat kai kuriais atvejais prisideda ir prie skatinimo dirbti nelegaliai. Ekspertų nuomone, žemas žmonių sąmoningumo lygis, visuomenès nelegalaus 
darbo tolerancija turi būti vertinama kaip dar viena nelegalaus darbo atsiradimo priežastis.

Ekspertinio tyrimo metu paaiškèjo, kad nelegalaus darbo kontrolès efektyvumas Lietuvoje vertinamas tik patenkinamai. Pagrindinès problemos, neleidžiančios pasiekti geresnių rezultatų, yra: kontroliuojančioms institucijoms suteiktų ịgaliojimų ir kontrolès teisių trūkumas; teisinės bazès netobulumas; organizacinių - informacijos mainų, priemonių stoka; nepakankama pareigūnų kvalifikacija; materialinès bei techninès bazès nepakankamumas.

Taip pat ekspertai vertino VDI priemonių efektyvumą siekiant pagerinti nelegalaus darbo kontrolę. Respondentai akcentavo, kad įgyvendinti turimas priemones trukdo skiriamos ribotos lěšos dirbti po darbo valandų (viršvalandžius), naktimis, poilsio dienomis; VDI inspektoriams trūksta papildomų mokymų; trūksta didesnio institucijų bendradarbiavimo šiuolaikinėmis priemonemis, kas pagerintų darbo našumą, pagreitintų procesus; informacijos mainai yra pakankamai efektyvūs, tačiau praktikoje kartais vis dar pasitaiko biurokratinių kliūčių, neleidžiančių operatyviai gauti reikiamos informacijos; trūksta konkretumo dèl nelegalaus darbo reiškinių kontrolès privačiose valdose; nèra tinkamų igaliojimų dẻl nelegalių darbuotojų ar asmenų, nelegaliai vykdančių individualią veiklą siekiant gauti pajamų, sulaikymo.

Vis dèlto ekspertai skiria šias turimas priemones, kurios priskirtinos prie organizacinių - informacijos mainų, prevencijos - švietimo bei kontrolès priemonių, kaip pagrindinès, padedančios siekti didesnio nelegalaus darbo kontrolès efektyvumo:

- VDI atstovų (vadovybės) dalyvavimas apskričių koordinacinès tarybos kontrolès institucijų posèdžiuose gerina ir skatina inspektorių bendravimą žemesniu lygiu;

- Prevencijos ir švietimo priemonių efektyvumą rodo inspektavimų metu tikrinamujų subjektų išsakoma nuomonè, kad inspektoriai gali bet kada netikètai atlikti operatyvų patikrinimą. Sudarytas norimas ịspūdis, kad darant teisès pažeidimą inspektoriai gali bet kada patikrinti, nors faktiškai žmogiškieji resursai nėra pakankami;

- Didinamas patikrinimų su kitomis nelegalų darbą kontroliuojančiomis institucijomis skaičius;

- Mobilių nelegalaus darbo kontrolès grupių ịsteigimas padidino nelegalaus darbo atvejų nustatymo skaičiu, pagerino tyrimų kokybę.

Apibendrinant tyrimo metu gautą informaciją galima teigti, kad siekiant pagerinti VDI nelegalaus darbo kontrolès efektyvumą ir spręsti kovos su nelegaliu darbu kontrolès efektyvumo problemą Lietuvoje, būtina kompleksiškai pašalinti kliūtis iš valstybės vykdomos socialinès ekonominès politikos ir nelegalaus darbo kontrolès teisinès bazès bei patobulinti nelegalaus darbo reiškinius kontroliuojančių institucijų koordinavimo priemones. Ydinga socialinès paramos sistema, nevisaverte teisinè bazè, nevisavertis informacijos pasidalijimas suponuoja nelegalaus darbo kontrolès efektyvumo stoką. 


\section{Išvados}

1. Atlikta nelegalaus darbo atsiradimo priežasčių teorinė analizė parodė, kad valstybės vykdoma ekonominè ir socialinė politika sudaro sąlygas atsirasti nelegalaus darbo reiškiniui Lietuvoje. Pagrindinès nelegalaus darbo reiškinių atsiradimo priežastys yra:

a) per didelè mokesčių našta, neatitinkanti valstybės patvirtintų socialinės ekonominès politikos iškeltų tikslų - kurti stabilią makroekonominę aplinką, paremtą konkurencingu, sparčiu ekonomikos augimu, žemu nedarbo lygiu ir stabiliomis kainomis;

b) asmenų ir įmonių ịsitraukimas į neteisètą veiklą, siekiant išvengti ar nuslèpti mokesčius;

c) valstybės vykdoma politika darbo rinkos bei užimtumo srityse - oficialaus darbo neradimas;

d) galimybè nelegaliai dirbantiems asmenims neteisètai gauti bedarbio ar socialinio aprūpinimo pašalpas.

2. Ivertinus nelegalaus darbo kontrolès problemas Lietuvoje ir Europos Sąjungoje nustatyta, kad pagrindinès nelegalaus darbo kontrolès efektyvumo problemos yra:

a) tarptautinio bendradarbiavimo stoka pirmiausia dél to, kad nėra bendros informacinès bazès;

b) Europos Sąjungos mastu neprieita prie platesnio ir bendresnio požiūrio ị nelegalaus darbo problemą;

Lietuvoje nelegalaus darbo kontrolè yra maksimaliai sutelkta darbo teisès srityje, tačiau nėra orientuojamasi į mokesčių reguliavimo sritį;

3. Ekspertinio tyrimo metu paaiškejjo, kad nelegalaus darbo kontrolès efektyvumą Lietuvoje ekspertai vertina patenkinamai. Pagrindinès problemos, neleidžiančios pasiekti geresnių rezultatų, yra:

a) kontroliuojančioms institucijoms suteiktų kontrolès teisių trūkumas;

b) teisinès bazès netobulumas;

c) organizacinių - informacijos mainų priemonių stoka;

d) nepakankama pareigūnų kvalifikacija;

e) materialinès bei techninès bazės nepakankamumas.

4. Atlikta nelegalaus darbo kontrolès efektyvumo analizè parodè, kad Lietuvoje yra dvi nelegalaus darbo atsiradimo priežastys:

a) socialinė ekonominè aplinka;

b) žmonių požiūris ị nelegalų darbą.

Ydinga socialinès paramos sistema, nevisavertè teisinè bazé, kontrolès teisių trūkumas, nevisavertis informacijos pasidalijimas tarp kontroliuojančių instituciju suponuoja nelegalaus darbo kontrolès efektyvumo stoką. 


\section{Literatūra}

1. Communication from the commission on undeclared work. COM (98) - 219. Final. Brussels, 1998 http://aei.pitt.edu/5111/1/5111.pdf [žiūrèta 2013-04-22].

2. Dekker, H. et al. Joining up the fight against undeclared work Europe. Final report. „Regioplan“, Amsterdam, 2010.

3. Europos ekonomikos ir socialinių reikalų komiteto nuomonè dèl Pilietinès visuomenès vaidmens kovojant su nelegaliu darbu. (2005/C 255/12). http://eur-lex.europa.eu/ LexUriServ/LexUriServ.do?uri=CELEX:52005IE0385:LT:HTML [žiūrèta 2013-0422].

4. Gyvenimas ir darbas Europoje. Metraštis 2009 m. „Eurofound“. http://www. eurofound.europa.eu/pubdocs/2010/16/1t/1/EF1016LT.pdf [žiūrèta 2013-06-15].

5. Guogis A. Dèl Lietuvos socialinès apsaugos sampratos. http://www.bernardinai. 1t/straipsnis/2007-07-17-arvydas-guogis-del-lietuvos-socialines-apsaugossampratos/4433 [žiūrèta 2013-04-27].

6. Kovos su nedeklaruojamu darbu stiprinimas. Europos bendrijų komisijos komunikatas KOM(2007) 628. Briuselis, 2007.

7. Krumplytė. J. Šešèlinės ekonomikos samprata ir priežasčių analizė. Ekonomika ir vadyba: aktualijos ir perspektyvos. 2008. 4 (13). 238-250.

8. Kuodis R. Viešųų finansų krizė Lietuvoje ir jos padariniai. Studijai „Lietuvos tauta: būklès ir raidos perspektyvų analizė“, 2006. http://neris.mii.lt/ ekonomika/Econlib/ Kuodis_2006a.pdf [žiūrèta 2013-04-24].

9. Labour inspection in Europe: fighting undeclared work and trafficking. ILO 2010. http://www.ilo.org/wcmsp5/groups/public/---ed_dialogue/lab_admin/documents/ publication/wcms_120319.pdf [žiūrèta 2013-06-15]. www.ec.europa.eu/social/BlobS ervlet?docId=6676\&langId=en [žiūrèta 2013-06-15].

10. Leontjeva K. Tai vis dèlto maži ar dideli mokesčiai Lietuvoje? Lietuvos laisvosios rinkos institutas. http://www.delfi.lt/news/ringas/lit/kleontjeva-tai-vis-delto-mazi-ardideli-mokesciai-lietuvoje.d?id=52105129 [žiūrèta 2013-04-24].

11. Lietuva patenka ị sunkiausios mokesčių naštos šalių dešimtuką. http://www.lrytas. lt/-13075230531307016610lietuvapatenka\%C4\%AFsunkiausiosmokes\%C4\%8Di\%C5 $\%$ B3-na\%C5\%A1tos\%C5\%A1ali\%C5\%B3-de\%C5\%A1imtuk\%C4\%85.htm [žiūrèta 2013-04-24].

12. Lietuvos išlaidos socialinei apsaugai - tarp mažesnių ES. http://www.delfi.lt/ news/daily/lithuania/lietuvos-islaidos-socialinei-apsaugai-vienos-mazesniues.d?id=60126753 [žiūrèta 2013-04-27].

13. Lietuvos Respublikos Vyriausybės nutarimas Nr. 1407 „Dél nelegalaus darbo reiškinių kontrolès koordinavimo“. Valstybės žinios. 2001, Nr. 99-3558.

14. Mačiulis N. Neoficialaus darbo užmokestis Lietuvoje per metus sudaro 7 mlrd. litų. http://www.swedbank.lt/lt/articles/view/1303 [žiūrèta 2013-04-15].

15. Martinkus B. ir kt. Darbo išteklių ekonomika ir valdymas: vadovèlis. Kaunas: Technologija, 2006.

16. Measures to tackle undeclared work in the European Union. „Eurofound“, 2008. http:// www.eurofound.europa.eu/pubdocs/2009/25/en/1/EF0925EN.pdf [žiūrèta 2013-05-30]. 
17. Mokesčiai ir mokesčių administravimas. Lietuvos laisvosios rinkos institutas. http:// archive.is/VNrc [žiūrèta 2013-04-24].

18. Nelegalaus darbo atvejų padaugèjo trigubai. balsas.lt: internetinis naujienų žurnalas: 201208 22, Vilnius, 2012, p. 1. http://www.balsas.lt/naujiena/615790 [žiūrèta 201304-21].

19. Nelegalus darbas. Lietuvos Respublikos socialinès apsaugos ir darbo ministerija. http://www.socmin.lt/lt/darbo-rinka-uzimtumas/darbo-teise/nelegalus-darbas.html [žiūrèta 2013-04-22].

20. Pocius A., Okunevičiūtė-Neverdauskienè L. Neoficialaus užimtumo Lietuvoje ivertinimas. Lietuvos statistikos darbai. 2007. 6-15. Provision of deficit and debt data for 2011 - second notification. „Eurostat“. http://epp.eurostat.ec.europa.eu/cache/ITY PUBLIC/2-22102012-AP/EN/2-22102012-AP-EN.PDF [žiūrèta 2013-04-27].

21. Rakauskienė O. G. Valstybės ekonominė politika: monografija. Vilnius: MRU leidybos centras, 2006.

22. Renooy, P. et al. Undeclared work in an enlarged European Union. European commission. 2004. http://www.ec.europa.eu/social/BlobServlet?docId=2652\&langId =en [Žiūrèta 2013-04-23].

23. Steponavičienė G. Lietuvos socialinè politika ir pasaulinè patirtis. http://www. freema.org/index.php/temos/kitos_temos/skurdo_politika/pranesimai_prezentacijos/ lietuvos_socialine_politika_ir_pasauline_patirtis/2173;read;1 [žiūrèta 2013-04-27].

24. Undeclared work. Summaries of EU legislation. http://europa.eu/legislation summaries/employment_and_social_policy/job_creation_measures/c11710_en.htm [žiūrèta 2013-04-22].

25. Žukauskas V. Lietuvos ekonomikos tyrimas 201/2013(2). Vilnius: Lietuvos laisvosios rinkos institutas. 2013, 10-13. http://files.lrinka.lt/LET2013_12_2/LET2012-13-2.pdf [žiūrèta 2013-04-24].

\section{Aleksandras Patapas, Nerijus Gudonis}

\section{Undeclared Work Control Efficiency Problem in Lithuania}

\section{Summary}

The aim of this article is to assess the current situation of the undeclared work control system in Lithuania and specify problem solving directions. The authors of the article seek to identify main problems and possible solutions associated with undeclared work control efficiency. Theoretical analysis is based on the Lithuanian laws and other legislation analysis, European Union document analysis, systematic analysis of scientific literature, analysis of statistical data. The research was conducted in January 2014, by using semi-structured expert survey. Inspectors of the Lithuania State Labour Inspection participated in this survey. An expert survey showed that in Lithuania there are two causes of undeclared work: State Control of socio-economic policy and the people's attitude to undeclared work. The hypothesis was rejected. The undeclared work control efficiency problem can be solved by transforming the state's socio-economic policy, undeclared work control legislation, increasing the qualifications of control officers, improving controls institutions material, information and technical databases, improving institutional coordination control measures. 
Aleksandras Patapas - Mykolo Romerio universiteto Politikos ir vadybos fakulteto Viešojo administravimo katedros docentas, socialinių mokslų daktaras.

E. paštas: patapas@mruni.eu

Nerijus Gudonis - Mykolo Romerio universiteto Politikos ir vadybos fakultetas magistrantas.

E. paštas: nerijus.gudonis@gmail.com

Aleksandras Patapas, Doctor of Social Sciences, Mykolas Romeris University, Faculty of Politics and Management, Department of Public Administration, Associate Professor.

E-mail: patapas@mruni.eu

Nerijus Gudonis, Mykolas Romeris University, Faculty of Politics and Management, Master student.

E-mail: nerijus.gudonis@gmail.com

Itteiktas 2014 m. rugsèjo 10 d.; recenzuotas; parengtas spausdinti lapkričio mèn. 